\title{
PROGRESS IN THE DEVELOPMENT OF GENERAL PRACTICE / FAMILY MEDICINE IN THE CITY OF SAINT PETERSBURG (RUSSIAN FEDERATION)
}

\author{
U. Gillan, R. McQuiston, O. Slevin
}

Healthcare Research \& Development Group*, University of Ulster, Belfast, Northern Ireland, United Kingdom

In previous years, indeed in some respects preceding the establishment of the Russian Federation, consideration had been given to the establishment of new approaches to general medical practice in Russia. Particular attention centred upon the establishment of Family Medicine and the preparation of doctors as Family Practitioners to advance this initiative. A number of pilot studies were initiated, including in the city of Saint Petersburg. These were intended to provide real-world opportunities to test and develop new and more effective approaches to primary health care that would more efficiently integrate with secondary care. The authors were involved in the initial pilot studies in the mid to late 1990s and subsequent follow-up projects to further advance the initiatives in the early years of the $21^{\text {st }}$ century (2002-2010). This brief paper reports on a review of progress made in respect of the above initiatives. It is not at this time a comprehensive evaluation of the healthcare systems as they now operate. The authors nevertheless present some indications of satisfactory progress across a range of practices, some insights into challenges that have arisen, and some suggestions that might be helpful in the current rounds of strategic planning for health.

Keywords: primary care; secondary care; general practice; family medicine; family practitioner; polyclinics; specialist $\mathcal{E}$ general services; quantitative research; qualitative research; mixed methods; bricolage.

\section{РАЗВИТИЕ ОБЩЕЙ ВРАЧЕБНОЙ ПРАКТИКИ / СЕМЕЙНОЙ МЕДИЦИНЫ В САНКТ-ПЕТЕРБУРГЕ (РОССИЙСКАЯ ФЕДЕРАЦИЯ)}

\author{
У. Гиллан, Р. МакКуистон, О. Слевин
}

Группа исследования и развития здравоохранения *, Ольстерский университет, Белфаст, Северная Ирландия, Великобритания

() У. Гиллан, Р. МакКуистон, О. Слевин

В предшествующие годы в Российской Федерации большое внимание уделялось разработке новых подходов к общей врачебной практике. Особое внимание было сосредоточено на создании системы общей врачебной практики (семейной медицины) и подготовке семейных врачей. Был проведен ряд пилотных исследований, в том числе в Санкт-Петербурге. Эти исследования были направлены на обеспечение условий для тестирования и развития новых, более эффективных подходов к первичной медико-санитарной помощи, которые лучше интегрируются с другими видами медицинской помощи. Авторы участвовали в начальном пилотном исследовании в середине и конце 1990-х гг. и в последующих проектах по дальнейшему развитию системы общей врачебной практики в 2002-2010 гг. В данной статье представлены результаты, достигнутые при решении вышеупомянутых задач. Авторы не дают полную комплексную оценку всей системы здравоохранения в ее современном виде, тем не менее представленные данные свидетельствуют о прогрессе в целом ряде направлений практической деятельности. В обзоре рассмотрены проблемы, возникшие при реализации новых подходов, а также предложения, которые могут быть полезными для стратегического планирования развития здравоохранения.

Ключевые слова: первичная медико-санитарная помощь; специализированная медико-санитарная помощь; общая врачебная практика; семейная медицина; поликлиника; специализированные и общие службы; количественные исследования; качественные исследования; смешанные методы; бриколаж.

* The Healthcare Research \& Development Group was established in 2006 as an international development unit within the Health \& Life Sciences faculty of the University of Ulster.

* Группа по исследованиям и разработкам в области здравоохранения была создана в 2006 г. как подразделение, занимаюееся вопросами международного развития на фракультете здравоохранения и наук о жизни Университета Ольстера. 


\section{Introduction: Beginnings, Challenges and New Directions}

Beginnings. As a developed nation in the $20^{\text {th }}$ century the Union of Soviet Socialist Republics (USSR) - and later the Russian Federation - experienced all the progressive developments associated with modernity. Industrial development there, like elsewhere, proceeded through scientific and technological advances into a new post-industrial era. These developments also impacted on issues of health and wellbeing. Advances were made in the prevention, diagnosis and treatment of 'old' diseases such as Polio, Tuberculosis, Measles, Diphtheria and Typhoid. As these old infectious diseases were being contained or even eradicated, new diseases and new health challenges were emerging. To an extent, the disorders of excess and plenty replaced the scourges of infectious disease. Cardio-vascular disorders, obesity, diabetes, asthma and other respiratory disorders (often linked to smoking and industrial pollution), some malignant diseases, alcoholism and drug misuse, and mental health challenges all increased. The expectations of modernity that utopian states of health and wellbeing would emerge - were to an extent replaced instead by post-modern angst in respect of emerging health challenges.

Challenges. Across the span of the $20^{\text {th }}$ century the major population-decimating epidemics, famines (at least in developed countries) and world wars subsided. Major advances also occurred in environmental health (such as clean water, mostly adequate sewage and waste disposal, and food hygiene). These had significant positive impacts upon the general health and wellbeing of national populations in the West and other developed countries, and led to concomitant changes in terms of population increases and overall demographical profiles. As infant mortality and overall mortality rates fell, life expectancy increased and the numbers of vulnerable and older people increased. These trends placed greater demands upon health and social care services. To a large extent these trends were mirrored in the Russian Federation, although with some important deviations. As indicated in Figure 1 below, the general direction from the time of the Great Patriotic War (World War 2) until 1991, just before the ending of the USSR and inception of the Russian Federation, was a largely downward trend in Infant Mortality Rates (IMRs) [1].

While the above figure is a good indicator of positive health trends, it is also important to recognise the unique situation that pertains in respect of Russia. All countries of course have their unique features in respect of population and demography, culture, physical environment etc. However, Russia is the largest country in the world in terms of landmass. It extends from the Arctic to south Central Asia, across Europe and Asia - a total landmass of about 6.7 million sq $\mathrm{km}$. It is the $9^{\text {th }}$ most populace country on Earth, with a population of around 145 million, the greatest number living in the European part of the country, reflecting the inclement climate and remote physical terrain of large parts of the country.

The estimate since the above data for 1960 to 2017 suggests a current 2019 population estimated at 145.87 million, a decline from an estimated population of 146.3 million in 2015 [2]. Russia therefore is not completely in line with the trends in other developed countries, being one of a very few countries to be in negative population growth over the last two to three decades. As will be noted from Figure 2 above [3], while other developed countries such as Germany and Japan (also greatly affected by World War 2) have had sustained population growth and increases in life expectancy, Russia has been different: not only have overall population trends indicated declines in recent times, but also migration declines particularly in respect of inward immigration [4].

There are low birth rates among woman, combined with high rates of abortion. This may be attributed to economic decline and an unwillingness to procreate in less favourable circumstances. And it is suggested that there was a tendency in

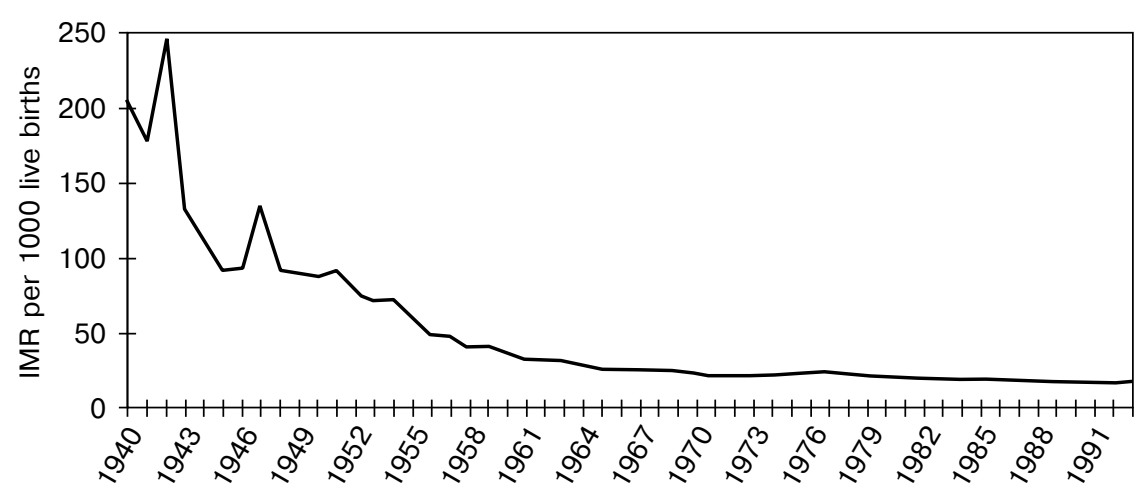

Fig. 1. Infant Mortality Rate: USSR \& Russian Federation [1] 
million
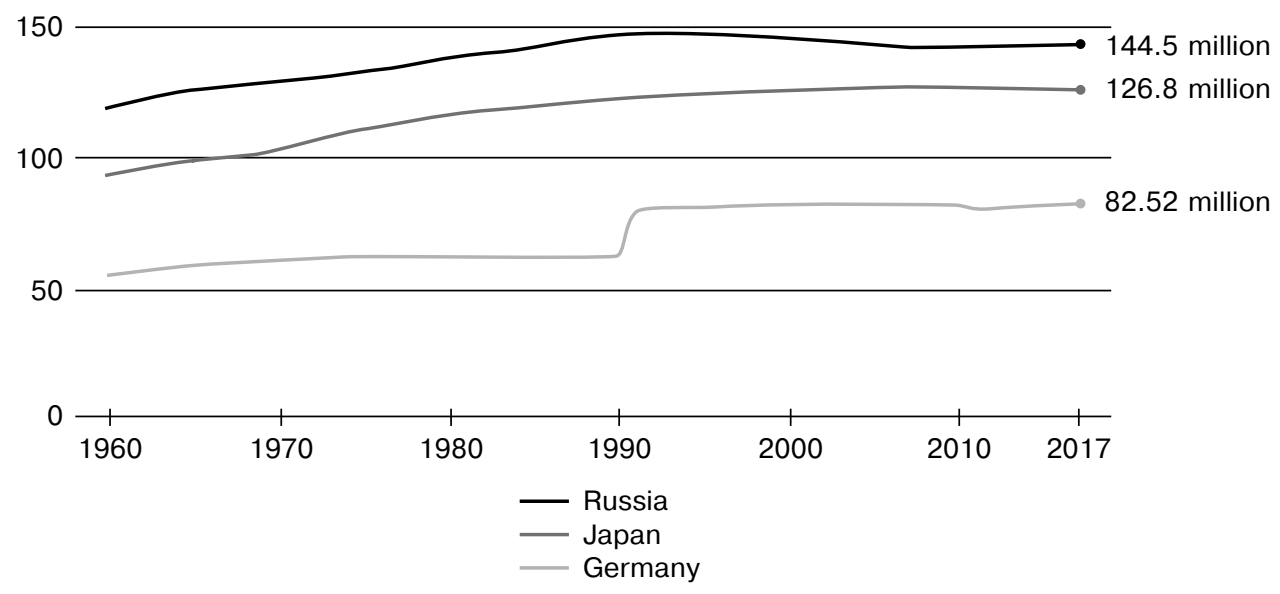

Fig. 2. Population dynamics: Russia, Japan and Germany (1960-2017) [3]

the USSR and extending into the present Russian Federation whereby abortion was and may still be used by many women as a means of birth control [5]. This has led to increasing concerns and a Government push for strategies to curtail the number of abortions. This issue of lower birth-rate and its impact upon population levels was compounded by other factors. Perhaps the most concerning of these was the high mortality rates among younger adults - men in particular. This can be causally related to alcohol consumption and social and economic patterns that may also have influenced deaths from suicide, accidents and violent deaths in younger male adults (with homicide for this group only exceeded in Columbia and parts of Mexico and USA). In this respect, it is notable that a previous Government campaign to address the ravages of alcoholism prior to the major social change of USSR disaggregation did have a notable positive impact upon mortality rates and life expectancy for a period.
However, this was not sustained, probably as a result of the major impact of the latter disaggregation.

At the time the pilot studies being reviewed in this paper were being conducted, the early stages of the massive socio-political shift from USSR to Russian Federation had not played out sufficiently to demonstrate trends more clearly. Nevertheless, as already being recognised by political leaders, major changes in the healthcare system were needed. This was increasingly clear from major health indices, such as the life expectancy data in Table 1 below [1], and also to those working within the healthcare system. There was a lack of fit between the idealistic paternal systems of healthcare previously in place and the challenges now being met [6]. It may thus be reasonable to assume that Russia is unique in a number of respects. On this argument, while it is important to consider developments in the healthcare field in general and globally, and best practices and

Life Expectancy in Russia (In years) [1]

\begin{tabular}{|c|c|c|c|c|c|c|}
\hline \multirow{2}{*}{ Year } & \multicolumn{3}{|c|}{ Russia } & \multicolumn{3}{|c|}{ United States } \\
\hline & Males & Females & Difference & Males & Females & Difference \\
\hline 1896 & 30.9 & 33.0 & 2.1 & - & - & - \\
\hline 1910 & - & - & - & 48.4 & 51.8 & 3.4 \\
\hline 1926 & 39.3 & 44.8 & 5.5 & 55.5 & 58.0 & 2.5 \\
\hline 1938 & 40.4 & 46.7 & 6.3 & 61.9 & 65.3 & 3.4 \\
\hline 1958 & 61.9 & 69.2 & 7.3 & 66.8 & 73.2 & 6.4 \\
\hline 1965 & 64.0 & 72.1 & 8.1 & 66.9 & 73.7 & 6.8 \\
\hline 1970 & 63.0 & 73.4 & 10.4 & 67.1 & 74.7 & 7.6 \\
\hline 1980 & 61.4 & 73.0 & 11.6 & 70.0 & 77.4 & 7.4 \\
\hline 1987 & 64.9 & 74.3 & 9.4 & 71.5 & 78.4 & 6.9 \\
\hline 1990 & 63.8 & 74.4 & 10.6 & 72.0 & 78.8 & 6.8 \\
\hline 1991 & 63.5 & 74.3 & 10.8 & 72.0 & 78.9 & 6.9 \\
\hline
\end{tabular}


lessons learned elsewhere, it is also vitally important that they are considered against a backcloth of what are unique circumstances.

The aforementioned differences between Russian systems and the health delivery systems of some Western countries were notable. The differences in the actual health threats and how the burden falls on men and particularly younger men, as identified by Shkolnikov and Meslé [1] and Rozenfeld [6] and others were also notable.

As pointed out by Toon [7], the Russian healthcare system also differs from many other developed countries in the sheer vastness of the enterprise. And as he also pointed out, the services when compared to other countries ranged from good, to bad, to just different. As also noted by Toon and his Russian colleagues (Toon, Vilks, Schlachter, Baranova et al.) [7] not only did the broad challenges to delivering healthcare confronted by most developed countries also confront Russia, but they were coloured by other specific Russian circumstances. These included the above specific demographic and epidemiological challenges (low birth rates, high abortion levels, high levels of alcoholism especially in younger adults, lower economic indices and exceptionally low immigration levels).

New Directions. The development of General Practice / Family Medicine (GP/FM) in Saint Petersburg through the Pilot Studies took place during a period of major change in Russia. The original Tacis primary care projects were conceived in 1993/4 and proceeded between 1995 and 1998. There were further extensions of the development work on primary health care in Moscow and Belgorod between 2002 and 2005, and on improving the health status of the Kaliningrad Region in 2006-2010. Just before the initial period of set-up of the original development projects in the early 1990s, Russia had undergone a major period of transformational change. Indeed some may have termed this every bit as revolutionary as the previous dissolution of Tsarist Russia, or described it as a cataclysmic change that is even now still being worked through and possibly impacting on health and wellbeing.

Even before the disaggregation of the USSR, consideration was being given to the need for major changes to the country's health care system. Indeed, the Tacis projects considered here initially began within 2-3 years of the birth of the new nation.

In fact, well before the creation of the new state, leaders in the USSR were already recognising the need to review and modernise the Russian health services. In the final days of the USSR, leaders in health were recognising a health care system no longer fit for purpose. By the latter half of the 1980s, Soviet Health minister Yevgeni Chazov, was considering the introduction of the Family Doctor role. This position was supported by another ex-health minister, Igor Denisov, who identified the favourable implementation of Family Medicine and Family Doctors in Canada as a possible option in Russia $[8,9]$. In a sense, the scene was already being set for initiatives such as the Tacis projects discussed here. A number of sources had built upon the thinking of Chasov and Denisov by identifying limitations in the delivery of primary health care, and identified values in moving towards family medicine models [10-14].

By the time the original Tacis General Practice / Family Doctor pilots were moving beyond set up and into active pilot study status, the Russian Federation had issued its initial 'Fundamentals of the legislation of the Russian Federation on health protection No. 5487-1 of July 22, 1993' (Russian Federation, 1993-2007). Within this statute Article 22 The Family Rights includes the following wording [15]:

The State shall take care of the protection of the health of family members.

According to medical indications every person shall have the right to receive free consultations on family planning, socially significant and contagious diseases, on the medical and psychological aspects of family and marital relations, and also on medical-genetic and other consultations and examinations in the institutions of the state or municipal system of public health, with the aim of preventing the perpetuation of possible hereditary diseases in posterity.

By agreement between all the family members of age living together, the family shall have the right to choose the general practitioner (their family doctor), who makes house calls.

Thus, the family now had legal rights to family-orientated services and the choice of 'a family doctor'. Notably, a more recent update of the legislation, repealing the above legislation, has been issued. This is entitled 'Federal Law of the Russian Federation No. 323-FZ of 21.11.2011 on Basics of Health Protection of the Citizens in the Russian Federation as amended to 29 December 2015' (Russian Federation, 2011-2015). Here the corresponding Article - now Article 51 - lists rights of family members which are similar but different in some respects [16].

\section{Background to Current Review}

The review has its origins in the long-standing cooperation between the Russian and Northern Ireland health sectors, dating back to the late 1980s. A technical exchange programme, initiated in 1988, led to Northern Ireland's involvement in the first EU-funded health sector reform pro- 
gramme in the then Soviet Union. The EU Tacis Support for Health Systems Development project was identified in the period 1993-1994 and the project proper ran from 1995 to 1998. A main theme of the project was support for the development of general practice based primary health care in selected pilot regions in Russia. At the time, primary health care was delivered typically by teams of primary care therapists, obstetricians / gynaecologists and paediatricians based in polyclinics. There were no general practitioners or family doctors.

Saint Petersburg was one of four pilot locations in which the concept of GP/FM-based primary health care was to be developed and trialled, the other three being Samara (Volga Region), Ekaterinburg (Urals Region) and Kemerovo (Western Siberia). A set of principles (the Smolninskiy Principles) was developed and agreed which would be used to inform the experimental process. Sixteen pilot GP/FM practices were established, four in each pilot location, and Russian primary care doctors were trained to deliver the new services. Initially, the GP training took place in Belfast, Northern Ireland (UK) but, by using a trainingof-trainers approach, the ground was prepared for subsequent GP training to take place in the Russian pilot regions.

The Government of the Russian Federation and the Commission of the European Union judged the Tacis project to have been successful in achieving its objectives. General Practice based primary health care had been established in a small way, and GP services were available to a small but significant proportion of the population in each of the pilot regions.

Had events then followed their normal course, it is unlikely that there would have been any further engagement between the Russian and Northern Ireland health sectors in this sphere of activity. However, because of the strength and duration of the collaboration that had been established, cooperation continued in the succeeding years, especially in relation to the work in Saint Petersburg. In parallel with involvement in further Tacis interventions in Moscow and Belgorod (Primary Health Care Development project, 2002-2005) and Kaliningrad (Improving the Health Status of the Kaliningrad Region, 2006-2010), contact was maintained with the Public Health Committee of Saint Petersburg. It became clear that, of the four pilot regions involved in the first Tacis project, Saint Petersburg was showing the most promise in terms of roll out of the concepts and practice of GP-based primary health care.

In 2015, an agreement was reached between the Public Health Committee and Ulster University to establish a joint Health Policy Research Group, the remit of which would be to exchange information on healthcare systems and healthcare financing systems in the European Union and Russia and to carry out joint operational research on a wide variety of healthcare issues. The first research programme to be undertaken by the group was to focus on the characteristics of primary health care facilities in the city of Saint Petersburg, in particular the extent to which these facilities were functioning in line with the Smolninskiy Principles elaborated under the original Support for Health Systems Development project. This programme started in 2015 and, through targeted missions, has involved an assessment of current GP/FM services in selected districts of the city. The findings to date are reported in the following sections, preceded by a brief outline of the methods employed.

\section{Methodological orientation}

The methods used for the review activities from 2015 until the present were essentially within a broad 'mixed methods' orientation. These drew upon the evaluative research methods for addressing the original pilot project activities. Appendix One at the end of this paper outlines the approaches adopted in one such pilot project: the pilot on Improving the Health Status of the Kaliningrad Region, 2006-2010. Essentially, the orientation is one of following the broad framework of what is referred to as the rapid review approach [17]. In each instance drawing upon the broad objectives of the pilot project and conducting a scoping study [18] into suitable methods, a tailor-made review strategy emerged. This incorporated, as illustrated in Appendix One data collection and analysis methods such as Textual Analyses of Policy and Planning documents, User and Policy Focus Groups, In-Depth Interviewing, Delphi Study Rounds, Group Interviews / Discussions. The 'sample' framework in Appendix One was specific to the Kaliningrad project, but the framework varied according to specific aspects of different pilot projects.

Within healthcare, importance has been attached to the idea of Evidence Based Medicine and where possible basing treatment and care on the best available quantitative objective scientific evidence [19] — see Table 2 below. But

Table 2

Broad Orientations in Research \& Practice [19]

\begin{tabular}{|l|l|}
\hline Quantitative orientation & \multicolumn{1}{|c|}{ Qualitative orientation } \\
\hline Objective & Subjective \\
\hline Seeks factual knowledge & Seeks understanding \\
\hline Measures phenomena & Explores meanings \\
\hline
\end{tabular}




\section{Theory and practice}

it is also recognised that health, and ill health, and how these are addressed, are highly experiential matters. Thus, as again illustrated in Table 2 below, a qualitative subjective dimension is also important. This recognition has increased over the years. The limits of both quantitative and qualitative research have been recognised, but the needs for both as valuable sources of Evidence INFORMED Healthcare as opposed to Evidence BASED Medicine has also gained traction as a useful orientation. The mixed methods orientation referred to above adopts this broader approach.

This aforementioned mixing of methods to suit the specifics of the situation, sometimes referred to as bricolage, is often adopted in qualitative social sciences [20-21]. This draws upon the French word bricoleur, which relates to a handyman or Jack-of-all-trades, who is traditionally an odd-job man who does small jobs for people. A characteristic of such work-persons is their adaptability to working with a myriad of problems in specific and often unique circumstances, using not only standard tools but tools they have modified or designed for use in specific circumstances. This is also what bricoleur-researchers do. They design methods and even modify or design specific instruments to suit particular research issues or problems. Although entirely new tools of enquiry were not constructed for this review, the enquiry design was informed by the issue (primary health care development) in specific unique situations, and not slavishly tied to inappropriate rigid re- view designs; thus using rapid review approaches with a realistic evaluation perspective [17-21]. Obviously, there was a need to anchor the review on core concepts of PHC [22]. WONCA had proposed six core competencies as follows: Primary Care Management, Community Orientation, Specific Problem-solving Skills, Comprehensive Approach, Person-centred Care, and Holistic Modelling, as illustrated in Figure 3. The similar framework represented by the Smolninskiy Principles developed a decade earlier (see Appendix Two) was clearly progressive in its conceptualisation, and a valid set of criteria for establishing progress in developing the GP/FM services.

While in the case of Saint Petersburg the specific methodology outlined in Appendix One was not utilised, the main stages of the review were utilised. That is, stages of: Information Collection, Analysis, Evaluation, and Policy Review involving exploration of documentary evidence, observational visits, group discussions and interviews. This was approached by a series of review visits wherein the latter aspects were addressed with key stakeholder groups. In effect, the idea of matching the method of the review to the issued being explored was thus being maintained. This was further structured by using the Smolninskiy Principles developed and agreed earlier in the Tacis initiative (see Appendix Two and above). On this basis the issues, drawn directly from the latter principles, were addressed (information collected, data / information analysed, evaluative judgements arrived at,

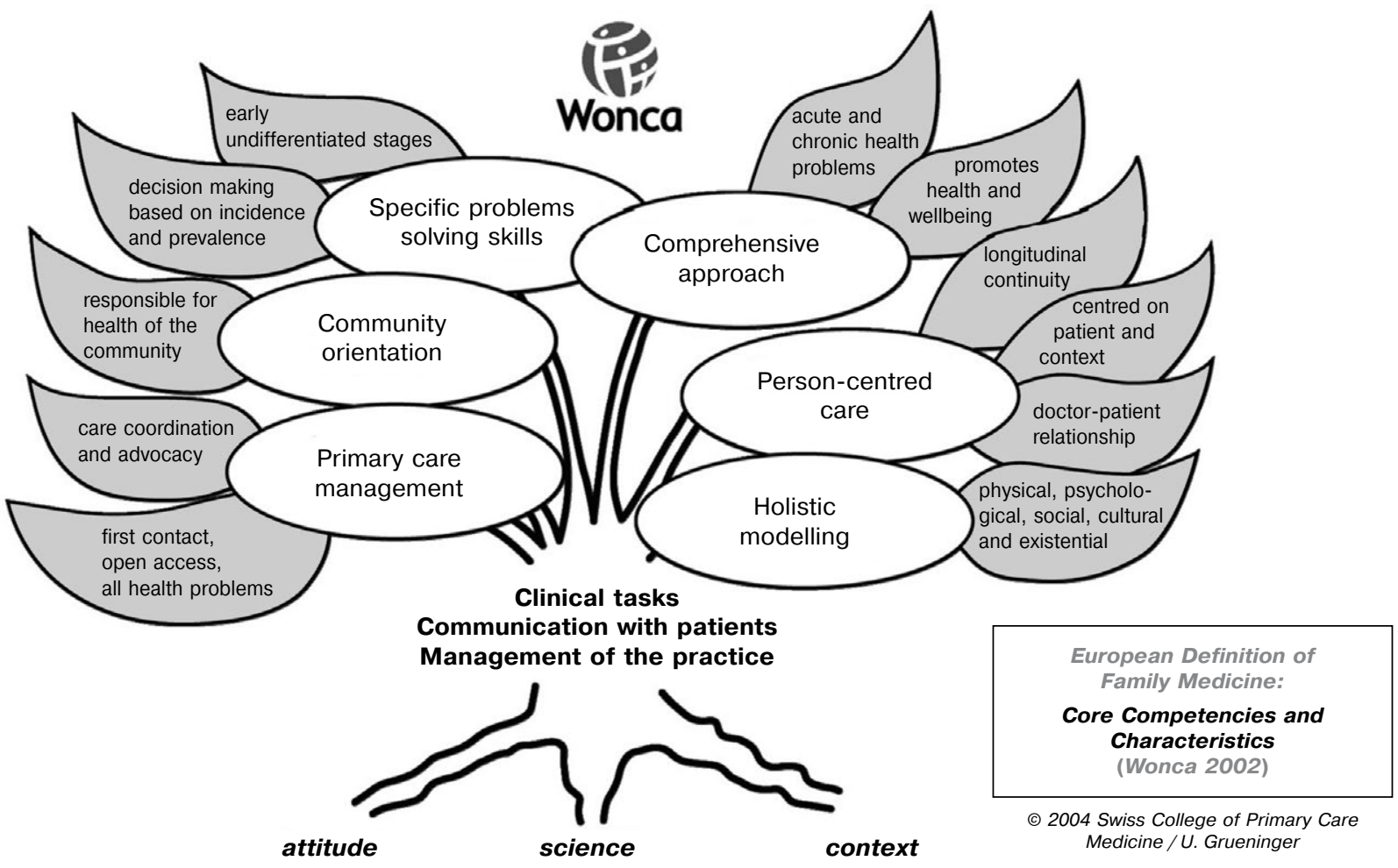

Fig. 3. The WONCA Framework for General Practice [22] 
and policy issues addressed). The nine issues so identified were:

- Positioning of General Practice/Family Medicine in the health system

- General Practice versus Family Medicine

- The Primary Health Care team

- Patient registration

- Holistic care

- Non-curative care

- Protocols, standards and the interface between different levels of care

- Monitoring \& Evaluation / Quality Assurance

- Education and Training/Continuing Professional Development

The remainder of the paper addresses these matters.

\section{Positioning of General Practice / Family Medicine in the health system}

There has been significant expansion of GP/FM services in the 20 years since the original Tacis project concluded. Approximately $20 \%$ of the city's population now has access to GP-based primary health care, with coverage reaching $40 \%$ in Primorskiy District. The issue of access has been accorded a high priority with planning approval for new housing developments including a requirement for appropriate associated primary care facilities to be provided. One of the principles on which the development of general practice has been based is that GP-based PHC should be the first point of contact with the health service and should act as the preferred location for the delivery of all health care services. The General Practitioner should act as the gatekeeper to the required services. GP-based PHC clearly is the first point of contact with the health service in those areas where it has been established and the gatekeeper role is operating effectively in these locations. The effectiveness of this approach has been demonstrated, for example through the monitoring of referral rates. State-owned General Practices have been shown to refer patients to hospitals less frequently than traditional polyclinic-based PHC teams. There are no separate statistics for the rate of referral by General Practices operating under the Public Private Partnership initiative.

This reduced rate of referral by general practice has the potential to increase the cost-effectiveness of the health service overall by limiting the volume of more expensive hospital care. Given that $80 \%$ of patients in the city are still receiving their primary care from traditional PHC teams, with their associated higher referral rates, there is some way to go before optimal cost effectiveness can be achieved. This is acknowledged implicitly by the Public Health Committee in the expressed preference for GP-based PHC which features in the strategic plan to 2024. It is notable however that no specific targets have been set for expanding the coverage of general practice. It seems likely that in the absence of such targets, the time frame for achieving universal coverage will be significantly prolonged. Another pre-requisite for maximising the economic impact of general practice is to transfer resources from hospital to community-based care in line with reduced referrals. There is no evidence of such transfers taking place or being planned for at the present time.

In line with the gatekeeper concept referred to above, access to specialist services should only be through referral by the General Practitioner except for accident and emergency cases. Clearly, there cannot be city-wide GP gate-keeping in a situation where $80 \%$ of the population have no access to GP services. It is encouraging however that where GP services do exist, patients appear to subscribe willingly to the gate-keeping role of their practice. This suggests that when universal GP coverage is achieved, gate-keeping will become a reality, whether or not the legislative provision allowing patients to consult the doctor of their choice is repealed.

\section{General Practice versus Family Medicine}

In the rest of Europe, General Practice and Family Medicine are usually viewed as one and the same. In Russia, the terms tend to be viewed differently, with General Practitioners seen as providing GP services for adults only whilst $\mathrm{Fa}-$ mily Doctors provide GP services for the whole family, including children. We are aware that there is federal legislation which has the effect of requiring separate facilities to be provided for children but we also noted during our February 2019 mission that this problem has been overcome in some GP offices including those operating under the Public Private Partnerships (PPP) initiative. By having separate contracts with adult and children's polyclinics, the PPP practices can provide GP services to the whole family - covering general, obstetric / gynaecological and paediatric services - thereby acting as true family medicine practices.

Some state-owned practices have also managed to find a way to function as true family medicine providers. In the districts we visited, 2 practices in Kalininskiy District, 3 in Primorskiy and 1 in Vyborgskiy provide services for adults and children. Some of these practices are PPP and some are state-owned. This suggests that those state-owned offices who feel that the current legislation prevents them from developing as true family medicine practices, may eventually find a way to achieve this. 


\section{Theory and practice}

The requirement for separate adult and children's services is of less significance at the polyclinic level. Provided a GP practice and, ideally, a particular GP within that practice, has an overview of the health status of the whole family, it is less important that back up services provided by supporting polyclinics should also be provided from a common location.

Speaking of this back up service, we were impressed with the health care model that is now emerging in Saint Petersburg, involving as it does not only General Practice / Family Medicine and hospital care but also intermediate care provided by re-modelled polyclinics. Polyclinics are still providing traditional PHC services for $80 \%$ of the city population but a proportion of them have evolved to provide an additional intermediate referral service for GPs, thereby extending the contribution that $\mathrm{PHC}$ can make to the overall delivery of care. At an earlier stage in the reform process, there was a school of thought that general practice should progressively replace polyclinic services and that polyclinics would eventually cease to exist.

It is clear from our experience in the United Kingdom generally and in Northern Ireland in particular, that there are limitations to the binary model of health care delivery. Currently general practices in Northern Ireland are over-burdened to the extent that, other than in an emergency, patients may have to wait for 3 to 4 weeks to get an appointment with their GP. At the same time, hospital outpatient departments are flooded with patients who should be using the GP services. The development of an intermediate level of service in Northern Ireland, still at community level but more specialised than the service offered by GPs, could at one and the same time offer support to the GP level and relief to the hospital outpatient level of care. It would be impractical to begin constructing new polyclinics to provide this service so the best option may be to go for outreach community clinics serviced by hospital specialists.

Saint Petersburg is in the fortunate position of having an existing polyclinic infrastructure which can progressively transform from providing first level PHC services on the traditional model to providing intermediate level care in support of the evolving general practice network. The polyclinics are currently offering both kinds of service during the transitional phase of PHC development, and appear to be doing so very successfully.

\section{The Primary Health Care team}

The principle that GP services should be provided by a $\mathrm{PHC}$ team, comprising general medical practitioners, primary care nurses, social workers and other primary care professionals, is now quite well respected in the developing GP services in Saint Petersburg. The traditional arrangement under which the nurse would act as an assistant to the medical practitioner no longer applies. Nurses on PHC teams now have their own distinctive roles, most significantly in relation to preventive services, screening services and immunisation. In relation to prophylaxis, nurses have a big involvement in managing the register, arranging medication, conducting home visits, providing information on blood testing etc.

There is some evidence of increased involvement of social workers in the work of the primary care team but this appears to be at an early stage of development. Social workers are under separate administrative control and this complicates the process of involving them in primary care teams.

Representatives of the Mandatory Health Insurance Fund are often located in polyclinics and can be consulted by patients, including those registered with general practitioners.

While other primary care professionals, such as physiotherapists and occupational therapists are not often to be found on general practice teams themselves, their services are usually accessible to general practice through the intermediate care back up of polyclinics. This holds true for both state-owned general practices and PPP practices though it appears that these linkages are more easily established by state-owned offices. We were told that PPP practices devote a lot of effort to integration with the state system and face some obstacles in achieving this. Particular issues in this regard relate to immunisation of children and screening.

\section{Patient registration}

It is a principle of general practice that each patient should be registered with a GP practice to ensure continuity and succession of care, taking account of the past medical, psychological and social history of the patient and his/her family. This is now universally the case in those parts of Saint Petersburg where there is access to general practice. In the case of state-owned practices, patients can register through the polyclinic registry office, use the polyclinic's automatic registry system or register on line. PPP practices have their own registration arrangements.

Registration with the polyclinic's traditional services does not guarantee continuity or succession of care as patients are likely to be seen by different doctors on different occasions. Registration with the GP-based services makes continuity of care more likely in view of the smaller team size and the more patient-oriented approach involved in general practice. 


\section{Holistic care}

Another principle of general practice is that in the management of the presenting condition, the PHC team should adopt a holistic approach, taking account of the patient's psycho-social circumstances. We saw evidence of this approach in the services being offered by both types of general practice in the districts of Saint Petersburg visited.

\section{Non-curative care}

In line with a further principle of GP-based PHC, we heard about services being provided in all the districts visited which extend beyond curative care, including screening, chronic disease management, health promotion and disease prevention. There is a special line of funding from the Mandatory Health Insurance Fund to cover these services and payments are based on a series of indicators developed for the purpose. We were told about individual patient plans and prophylactic examinations of patients which currently cover $48 \%$ of patients and are planned to reach 96\% of patients by the year 2024. Employers are expected to allow employees 1-2 days per year to facilitate prophylactic visits to health facilities - an impressive endorsement by the State of the benefits of prevention. In the field of chronic disease management, special centres have been established for the management of diabetes and chronic cardiovascular disease conditions. As mentioned earlier, nurses have a big involvement in all of these areas.

Comprehensive patient records are an important pre-requisite for a holistic approach to health care including screening, the identification of 'at risk' groups and the management of chronic disease. It was clear to us that such records are maintained very effectively at all levels of the system in Saint Petersburg and it is largely thanks to this fact and the priority accorded to prevention that so much progress has been made on all aspects of non-curative care.

\section{Protocols, standards and the interface between different levels of care}

Missions to date have not allowed us to explore in much detail the area of protocols and standards used to regulate activity within the primary care team. We have however been made aware of initiatives that have been taken to regulate activity at the interface between primary and secondary care and, indeed, between different levels of the primary care system. In Primorskiy District, an interesting project has been looking at patient flows inside and outside the polyclinic. Information flowing from this project is allowing doctors to refer patients more efficiently to specialists within the polyclinic (including as a back-up to general practice), for lab investigation / primary diagnosis, for more advanced diagnosis, to more high-tech polyclinics or for hospital admission.

\section{Monitoring \& Evaluation / Quality Assurance}

The monitoring and evaluation of the range, accessibility and quality of services is an essential component of the primary health care system. The ongoing evaluation of healthcare needs and priorities and the effectiveness of the service response are critical to the enhancement of quality, the effective use of resources and service development. We heard about an interesting project being piloted in Polyclinic No. 57 in Nevskiy District, involving the introduction of Japanese-style management approaches. Whilst this work is still at an experimental stage, it is showing considerable promise in terms of a more cost-effective approach to service delivery and has the potential to make a significant contribution to the ongoing evaluation of the service response to healthcare needs.

Experience in many European countries suggests that particular attention should be paid to the establishment of a mechanism whereby the product of research into service quality is incorporated into the strategic planning process. This ongoing cycle of policy development, strategic response, service delivery, evaluation and monitoring, leading to further development of policy, requires the structured engagement of representatives of health committees, health insurance companies, academic bodies and providers through professional associations. Such an arrangement would help to ensure that the lessons learned from evaluation, including those from the Japanese pilot project, are captured and applied for the benefit of the wider healthcare system.

In the missions to date, there has been insufficient time to fully assess the arrangements for quality assurance and its incorporation into the planning process.

\section{Education and Training / Continuing Professional Development}

In 2011, the Saint Petersburg State Medical Academy and the Medical Academy for Postgraduate Studies merged to form the Northwest State Medical University of Mechnikov. The new university provides education on General Practice for final year medical students and postgraduate training in general practice through a 2-year residency programme. General practitioners are also trained by three other medical universities in Saint Petersburg [1]. 


\section{Theory and practice}

The academy still provides training for polyclinic district doctors but now adds communication skills, complex problem solving, continuity of medical care, elderly care and palliative care to the curriculum, thereby bringing the training more into line with that for general practice. From 2017, all students are required to be involved in an accreditation procedure, following which they can take up a position as a District Therapist (without residency training and having had only 6,5 weeks PHC training in their final year). This training regime for District Therapists falls well short of what is required to ensure that traditional polyclinic teams can deliver holistic primary care comparable to that being delivered by General Practitioners / Family Doctors, and further underlines the importance of moving towards universal GP/FM coverage for Saint Petersburg.

\section{Conclusions}

Overall, we were impressed with the progress that has been made in rolling out general practice / family medicine in the past 20 years. There is very little that we would change and in fact, as indicated earlier, there are aspects of the evolving services that might usefully be considered as a contribution to the ongoing debate about health service reform in Northern Ireland. We offer the following suggestions as worthy of consideration, should the Health Committee wish to expedite realisation of the aspiration in the strategic plan to 2024, favouring the general practice model of Primary Health Care (PHC) delivery.

1. In rolling forward the strategic plan, it would be helpful to introduce staged targets for General Practice / Family Medicine development, for example to achieve coverage for a specified percentage of the city population by certain specified dates; in this way the time frame for achieving universal coverage could be significantly reduced.

2. As GP/FM expands, polyclinics should continue to evolve as providers of intermediate-level care, between GP/FM and hospital levels.

3 . In order to realise fully the economic benefits of the move towards general practice / family medicine, arrangements should be put in place to ensure that resources are progressively transferred from hospital care to primary care as GP/FM coverage increases and hospital referral rates decline.

4. Drawing on the experience of the practices that have already achieved it, efforts should be redoubled to find ways of overcoming obstacles to the development of true family medicine, thereby removing the perceived distinction between general practice (for adults) and family medicine (for adults and children).

5 . While on this occasion programme evaluation approaches in place were not analysed, a two-stage ongoing / formative and summative programme evaluation, incorporating clinical audit and based upon evidence-based protocols, in line with Article 10 of The Smolninskiy Principles (see Appendix Two), is suggested.

6. Efforts should be made to further adapt the training of District Therapists to facilitate delivery of more holistic primary care, pending the realisation of universal GP/FM coverage for Saint Petersburg?

In moving forward, it would be interesting to similarly consider progress in other parts of the Russian Federation where PHC pilot projects had been completed, as identified in this paper.

Sample Rapid Review Framework

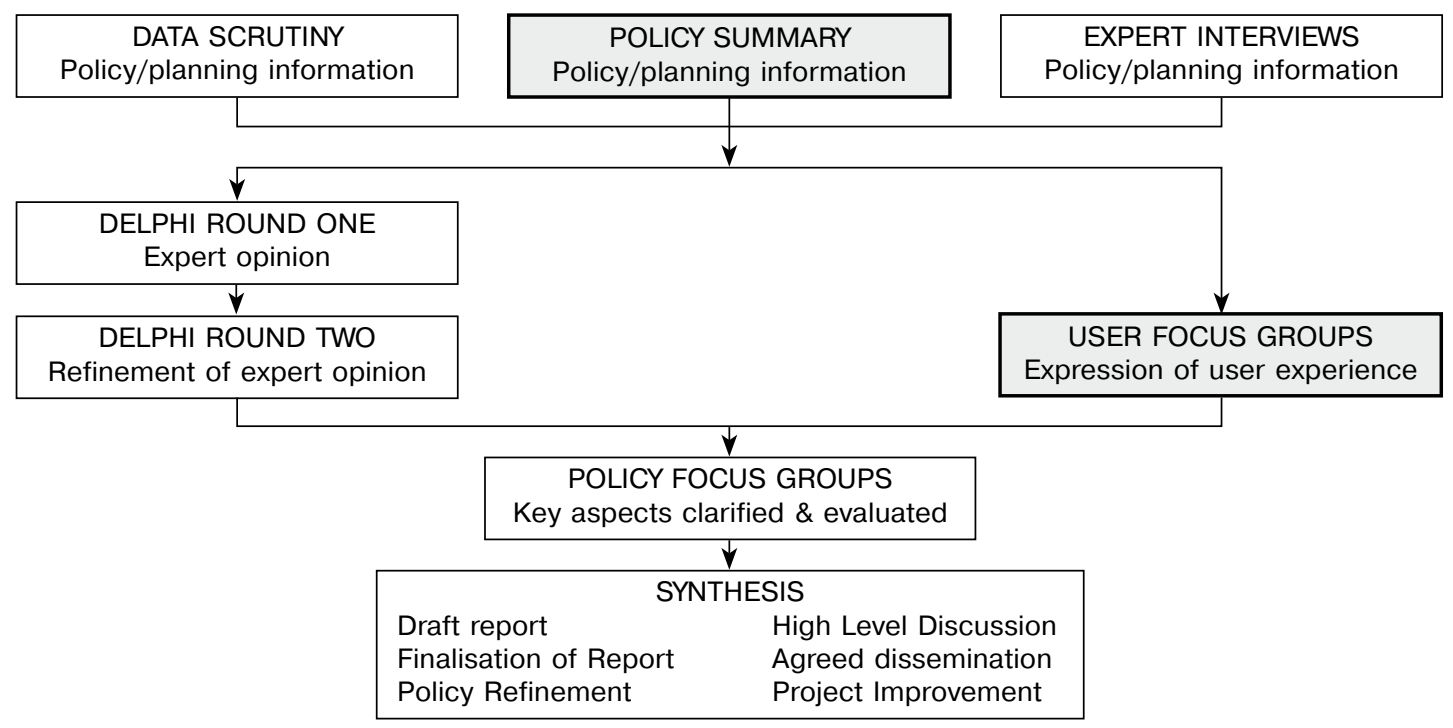

INFORMATION COLLECTION

ANALYSIS

EVALUATION 


\section{The Smolninskiy Principles}

Appendix two

A set of principles to guide the development of General Practice-based Primary Health Care (GP-based PHC) in the Russian Federation, agreed at a conference in the Smolninskaya Hotel, Saint Petersburg in October 1995, within the framework of the EU Tacis project Support for Health Systems Development.

1. GP-based PHC should be the first point of contact with the health service and should act as the preferred location for delivery of all health care services.

2. First contact care should be available to all members of the family and for all presenting conditions.

3. The General Practitioner should act as the 'gatekeeper' to the required healthcare services. Apart from accident and emergency cases, access to these services should only be through referral by the General Practitioner.

4. Services should be provided by a PHC team comprising general medical practitioners, primary care nurses, social workers and other primary care professionals, the precise skill mix depending on the identified needs of the practice population (gender- and age specific, morbidity etc).

5. Each patient should be registered with a GP practice to ensure continuity and succession of care, taking account of the past medical, psychological and social history of the patient and his/her family.

6. In the management of the presenting condition, the PHC team should adopt a holistic approach, taking account of the patient's psycho-social circumstances.

7. Services provided should extend beyond curative care to include screening, chronic disease management, health promotion and disease prevention.

8. The General Practitioner and the PHC team should maintain comprehensive patient records to facilitate a continuing holistic approach to health care including screening, the identification of 'at risk' groups and the management of chronic disease.

9. Protocols and standards should be developed to regulate activity within the primary care team and at the interface between primary and secondary care.

10. Quality assurance procedures, based on clinical audit, should be introduced to assess team member performance against evidence-based parameters for clinical care.

11. Team member performance should be supported by Continuing Professional Development and should be motivated by incentives designed to encourage adherence to the above principles.

\section{References}

1. Shkolnikov V, Meslé F. The Russian epidemiological crisis as mirrored by mortality trends. In: J. Da Vanzo, G. Farnsworth, ed. Russia's demographic crisis. RAND: Santa Monica, CA; 1996.

2. United Nations. Population Division of the Department of Economic and Social Affairs of the United Nations Secretariat. World Population Prospects; 2019 [accessed 2019 Dec 12]. Available from: https://population. un.org/WPP/Download/.

3. World Bank. Population estimates and projections. Washington DC: The World Bank; 2019 [accessed 2019 Dec 12]. Available from: https://datacatalog.worldbank.org/dataset/population-estimates-and-projections.

4. Bobylev Yu, Bozhechkova A, Mkrtchan N, et al. Monitoring of Russia's economic outlook: trends and challenges of socio-economic development, No. 12. Russian Presidential Academy of National Economy and Public Administration; 2019. 16 p.

5. Ferris-Rotman A. Putin's next target is Russia's abortion culture. Foreign Policy; 2017.

6. Rozenfeld BA. The crisis of Russian health care and attempts at reform. In: Russia's demographic crisis. Ed. by J. Da Vanzo, G. Farnsworth. RAND: Santa Monica, CA; 1996.

7. Toon PD, Vilks T, Schlachter K, et al. Reforming the Russian health service. Otherwise it might be convenient. Urgent aid, chronic penalties. Professional law breakers. Training general practitioners in Saint Petersburg. Training general practitioners in Gatchina. BMJ. 1998;317(7160):741-744. https://doi.org/10.1136/ bmj.317.7160.741.

8. Ryan M, Stephen J. General practitioners and family doctors in the Russian Federation. Br $J$ Gen Pract. 1996;46(409):487-489.

9. Sakhanovskaya M. Semeiny vrach v interere vuza. Meditsinskaya gazeta. 1993;22:8-9.

10. Rese A, Balabanova D, Danishevski K, Implementing general practice in Russia: getting beyond the first steps. BMJ. 2005;331(7510):204-207. https://doi.org/10.1136/bmj.331.7510.204.

11. Russia's demographic crisis. Ed. by J. Da Vanzo, G. Farnsworth. RAND: Santa Monica, CA; 1996.

12. Vertakova J, Vlasova O. Problems and trends of Russian health care development: $21^{\text {st }}$ International Economic Conference 2014, IECS 2014, 16-17 May 2014, Sibiu, Romania. Procedia Economics and Finance. 2014;16:34-39. https://doi.org/10.1016/S2212-5671(14)00771-0.

13. Groenewegen PP, Dourgnon P, Greß S, et al. Strengthening weak primary care systems: Steps towards stronger primary care in selected Western and Eastern European countries. Health Policy. 2013;113(1-2):170-179. https://doi.org/10.1016/j.healthpol.2013.05.024. 


\section{Theory and practice}

14. Starfield B. Toward international primary care reform. CMAJ. 2009;180(11):1091-1092. https://doi. org/10.1503/cmaj.090542.

15. Fundamentals of the legislation of the Russian Federation on health protection no. 5487-1 of July 22, 1993 (with the additions and amendments of December 24, 1993, March 2, 1998, December 20, 1999, December 2, 2000 , January 10, February 27, June 30, 2003, June 29, August 22, December 1, 29, 2004, March 7, December 21, 31, 2005, February 2, December 29, 2006, July 24, October 18, 2007). Available from: https://www.wto.org/english/ thewto_e/acc_e/rus_e/WTACCRUS58_LEG_270.pdf.

16. Russian Federation. Federal Law of the Russian Federation No. 323-FZ of 21.11.2011 on Basics of health protection of the citizens in the Russian Federation as amended to 29 December 2015. International Labour Organization; 1996-2014. Available from: https://www.ilo.org/dyn/natlex/natlex4.detail?p_lang=en\&p_isn=102297.

17. Arksey H, O’Malley L. Scoping studies: towards a methodological framework. Int J Soc Res Methodol. 2005;8(1):19-32. https://doi.org/10.1080/1364557032000119616.

18. Khangura S, Konnyu K, Cushman R, et al. Evidence summaries: the evolution of a rapid review approach. Syst Rev. 2012;1:10. https://doi.org/10.1186/2046-4053-1-10.

19. Slevin O. Approaches to healthcare research. In: Healthcare research: a textbook for students and practitioners. Ed. by P. Roberts, H. Priest. Chichester, UK: John Wiley \& Sons Ltd; 2010.

20. Kincheloe JL. Describing the bricolage: conceptualizing a new rigor in qualitative research. Qualitat Inq. 2001;7(6):679-672. https://doi.org/10.1177/107780040100700601.

21. Kincheloe JL. Redefining and interpreting the object of study. In: Rigour and complexity in educational research: conceptualizing the bricolage. Ed. by J.L. Kincheloe, K.S. Berry. Maidenhead: Open University Press; 2004.

22. World Organisation for National Colleges and Academies of General Practice/Family Medicine. The European definition of general practice / family medicine: 2011 Edition. WONCA Europe; 2011. Available from: https://www.woncaeurope.org/sites/default/files/documents/Definition\%203rd\%20ed\%202011\%20with\% 20revised\%20wonca\%20tree.pdf.

For citation: Gillan U, McQuiston R, Slevin O. Progress in the development of general practice / family medicine in the city of Saint Petersburg (Russian Federation). Russian Family Doctor. 2018;23(4):19-30. https://doi.org/10.17816/RFD18921.

Для цитирования: Гиллан У., МакКуистон Р., Слевин О. Развитие общей врачебной практики / семейной медицины в СанктПетербурге (Российская Федерация) // Российский семейный врач. - 2019. - Т. 23. - № 4. - C. 19-30. https://doi.org/10.17816/ RFD18921.

Information about the authors

Uel Gillan - MB, BCh, BAO, Primary Healthcare Specialist, Healthcare Research \& Development Group, Belfast, Northern Ireland, United Kingdom. E-mail: gillan47@hotmail.com.

Rob McQuiston - BSc, PhD, Health Policy \& Management Specialist, Healthcare Research \& Development Group, Belfast, Northern Ireland, United Kingdom. E-mail: rob_mcquiston@hotmail.com.

Oliver Slevin - BA, MA, PhD, RGN, RMN, Dip.Ed, Education \& Management Specialist, Healthcare Research \& Development Group, Belfast, Northern Ireland, United Kingdom. E-mail: oliver.slevin@gmail.com.
Информаиия об авторах

Уел Гиллан - бакалавр медицинских наук, бакалавр хирургии, бакалавр акушерства и гинекологии, специалист первичного звена здравоохранения, группа исследования и развития здравоохранения. Ольстерский университет, Белфаст, Северная Ирландия, Великобритания. E-mail: gillan47@hotmail.com.

Роб Маккуистон - бакалавр экономических наук, доктор философии, специалист по организации и управлению в здравоохранении, группа исследования и развития здравоохранения. Ольстерский университет, Белфаст, Северная Ирландия, Великобритания. E-mail: rob_mcquiston@hotmail.com.

Оливер Слевин - бакалавр гуманитарных наук, магистр гуманитарных наук, специалист общего сестринского дела, специалист сестринского дела в области психических заболеваний, специалистпреподаватель, специалист по образованию и управлению, группа исследования и развития здравоохранения. Ольстерский университет, Белфаст, Северная Ирландия, Великобритания. E-mail: oliver.slevin@ gmail.com. 